ISSN 2326-3350

\title{
Preparation and Evaluation of Olive Apple Blended Leather
}

Arsalan Khan ${ }^{1}$, Alam Zeb², Majid Khan'², Wasif Shah ${ }^{2}$

Review Article

${ }^{1}$ Agriculture Research Institute Tarnab, Peshawar

${ }^{2}$ Department of Food Science and Technology, University of Agriculture, Peshawar.

Abstract

The aim of the study was to evaluate a suitable combination of olive and apple pulp for the preparation of olive apple blended leather, stored at ambient temperature. The treatments were $\mathrm{T}_{0}, \mathrm{~T}_{1}, \mathrm{~T}_{2}$ and $\mathrm{T}_{3}$. The samples were wrapped in aluminum foil and then packed in polyethylene plastic bags and evaluation was carried out for a total period of 150 days. Physiochemically analysis; acidity and moisture and sensory characteristics; color, texture, taste and overall acceptability (using Larmond Scale) were evaluated at 30 days interval. A significant decrease was recorded in moisture (from $13.60 \%$ to $11.53 \%$ ), color (from7.20 to 4.60), taste (from 7.53 to 5.40), texture (from 7.23 to 5.13) and overall acceptability (from 7.33 to 4.85). A significant increase was recorded in acidity (from $0.67 \%$ to $0.84 \%$ ). Among all the treatments $\mathrm{T}_{3}$ was found most acceptable both physiochemically and organoleptically.

Keywords: olive fruit, leather, apple, storage

\section{*Corresponding Author:}

Arsalan Khan,

Agriculture Research Institute Tarnab,

Peshawar, Pakisthan.

E-mail:: arsalankhan.fst@gmail.com

Received: May 26, 2014

Accepted: July 01, 2014

Published: July 25, 2014

Citation: Arsalan Khan, Alam Zeb, Majid Khan, Wasif Shah (2014) Preparation and Evaluation of Olive Apple Blended Leather. Int J Food Sci Nutr Diet. 3(7), 134-137. doi: http://dx.doi.org/10.19070/23263350-1400026

Copyright: Arsalan $\operatorname{Khan}^{\circledR} 2014$ This is an open-access article distributed under the terms of the Creative Commons Attribution License, which permits unrestricted use, distribution and reproduction in any medium, provided the original author and source are credited.

\section{Introduction}

Fruit leathers are fruit base dehydrated product. They are chewy and tasty dried slabs made by putting fruit pulp into a mouldy surface. On drying it is put out and rolled. It has given the name due to its leathery appearances. Making leather benefits, in utilizing less sugar and more fruit flavors, useful for diabetic and health conscious consumers. Leather can be made from individual and mixed fruit in any proportion. It can be prepared from fresh, frozen and canned fruit. Drying of fruit leather involves removing of moisture, thus microbes can't grow. It also inactivates enzymatic activities. Moisture reduction makes it shrinked to occupy less space and facilitate transportation.

Olive (olea europaea L) is small tree fruit grown in temperate zones. Olive fruit is famous for its nutritious edible oil with a lot of health benefits. Other constituents are water, sugar, protein, oleouropein and anthocyanins. Oleouropein cause bitterness, must be removed (Gruenwald, 1998). Composition of olive fruit, moisture 65 to $75 \%$, lipids $10-15 \%$, reducing sugar $3-6 \%$, non reducing sugar $<0.3 \%$, fiber $1-4 \%$ and protein $1-2 \%$ (Garrido et al., 1997)
Apple (Malus Sylvestris) is a member of rosaceae family grown worldwide. Nutrition facts involve $84.7 \%$ water, $13.9 \mathrm{gm}$ carbohydrates, $0.3 \mathrm{gm}$ lipids, $0.4 \mathrm{gm}$ protein and vit.C $8 \mathrm{mg}$ per 100 from of edible fruit (Hussain 2001). Apples are rich source of antioxidants including flavoniods and polyphenols mainly occurs in its skin. Thus eating whole apple is recommended to obtained full health benefits (Hussain 2001).

\section{Materials And Methods}

The diseased free fruit was selected and washed with water in order to remove dust, and any other foreign material. Olive fruit was dipped in 2\% Sodium Hydroxide for 36 hours in order to remove the bitterness. After that fruit was washed several times with water so that the bitterness completely finished. After removal of bitterness pulp was obtained through pulper machine. Similarly apple fruit was washed, peeled, trimmed, cut and dipped in 1\% citric acid to prevent oxidation. Then the fruit was blended in order to get the pulp. Treatments of 20 degree brix were prepared by the addition of $0.1 \%$ sodium benzoate. After making fruit leather were wrapped in aluminum foil and packed air tightly in plastic bags. The leathers were kept at room storage for 5 months and studied at each interval of 30 days.

\section{Chemical analysis}

During room storage the leather were analyzed chemically for moisture and acidity by standard method of AOAC (2012).

\section{Organoleptic evaluation}

The olive apple blended fruit pulps were analyzed for color, taste, texture and overall acceptability by 10 panels of judges by using 9 points hedonic scale of larmond (1977).

\section{Statistical analysis}

The data were subjected to statistical analysis using 2-factorial CRD (Completely Randomize Design) and the means were differentiated by LSD (Least Significant Design) test $0.05 \%$ significant 
level as defined by Steel and Torrie (1997).

\section{Results And Discussions}

\section{Chemical analysis}

The moisture content of olive apple blended leather during storage of 150 days is indicated in table (1). The treatment and storage considerably affect the moisture content of the product. All the samples experienced moisture reduction during storage which might be due to evaporation from the samples surface (Ashaye et al., 2005; okilya et al., 2010).

The acidity content of olive apple blended leather sample showed significantly increased with each storage interval. Increased in acidity was reported by Ekanayake and Bandara (2002) in banana leather. This increase is due the methyl esterase activity which converts pectin in pectic acid. Reduction in moisture also increased the acidity of the dried product (Rao and Roy, 1980; Effah-Manu et al., 2013).

\section{Sensory analysis}

Leather was prepared from combination of olive and apple pulp in different proportion. All the samples were analyzed organoleptically for color, texture, taste and overall acceptability.

Table (3) revealed considerable $(\mathrm{P}<0.05)$ decline in color of the leather samples. Incorporation of 30 to $50 \%$ apple pulp did have much effect on color of the leather as represented (Table 3). Higher value of decrease was found in $\mathrm{OA}_{0}$ was $(30.00 \%)$ while lower deceased was shown by $\mathrm{OA}_{3}(17.39 \%)$. Color acceptability rating of the leather decreased with increase in drying time (Bauernfeind et al., 1981; Korkida et al., 1998).

Mean score of the judges for taste of the leather sample was significantly $(\mathrm{P}<0.05)$ effected by the increasing proportion of apple pulp (30 to $40 \%$ ). Table 4 represented color score of the olive apple blended fruit leather. Maximum declined in taste was revealed in $\mathrm{OA}_{\mathrm{o}}(30.16 \%)$ while minimum decrease was noticed in $\mathrm{OA}_{3}(16.22 \%)$. The taste of leather is contributed to the sugar content in fresh pulp. High amount of sugar beyond optimum level, may affect the taste score of the product (Jain and Nema. 2007). Sweetness rating may also depend on the type of fruit and may also vary during storage (Ashaye et al. 2005). However, guava leather and pawpaw leather shown maintain acceptable sweetness ratings within a study period of two months (Babalola et al., 2000). Mean score of olive apple blended leather for texture decreased during the storage interval from 6.70 to 5.08. Highest fall in texture value was recorded in $\mathrm{OA}_{0}(32.73 \%)$ followed by $\mathrm{OA}_{1}(26.15 \%)$, while minimum decrease occur in $\mathrm{OA}_{3}(16.05 \%)$ followed by $\mathrm{OA}_{2}(25.37 \%)$. The results are in agreement with the conclusions of Babalola et al. (2000) who reported that High temperatures and long drying times are associated with lower moisture content and harder texture. Differences in texture of leathers could also be due to variations in genetic makeup of the fruit, rate of water absorption from the surroundings and protein content of the fruit among others. The overall acceptability olive apple blended fruit leather was significantly affected $(\mathrm{P}<0.05)$. This shows that addition of apple pulp to leather were found more acceptable as compared to leather without apple fruit. General comments by panellists indicated that laboratory made mangosweet potato leather was "aesthetically appealing, very fruity, and sweet”. Overall acceptability generally related to all sensory attributes. It is reported that the acceptability of fruits and vegetables is influenced by their aroma by Karmas and Harris. (1998). Similar results were found by Iman et al. (2011) during physio chemical analysis and quality evaluation of intermediate moisture in apple slices.

\section{Conclusion}

In this research, olive apple blended leather was prepared at different ratio of olive and apple. From this study it is concluded that leather $\mathrm{T}_{3}$ (olive pulp (50\%) + apple pulp $(50 \%)+0.1 \%$ sodium benzoate) was accepted both organoleptically and physiochemi-

Table 1. Effect of treatment and storage interval on moisture content of olive apple blended leather

\begin{tabular}{|c|c|c|c|c|c|c|c|c|}
\hline \multirow[t]{2}{*}{ Treatments } & \multicolumn{6}{|c|}{ Storage Intervals (Days) } & \multirow[t]{2}{*}{$\%$ decrease } & \multirow[t]{2}{*}{ Mean } \\
\hline & Initial & 30 & 60 & 90 & 120 & 150 & & \\
\hline \multicolumn{9}{|c|}{ Moisture rate } \\
\hline OA0 & 12.3 & 11.9 & 11.3 & 10.9 & 10.3 & 10 & 18.7 & 11.12 \\
\hline OA1 & 13.8 & 13.4 & 13 & 12.8 & 12.3 & 11.7 & 15.22 & 12.83 \\
\hline OA2 & 14 & 13.7 & 13.1 & 12.8 & 12.4 & 12 & 14.29 & 13 \\
\hline OA3 & 14.3 & 14 & 13.6 & 13.2 & 12.8 & 12.4 & 13.29 & 13.38 \\
\hline Mean & 13.6 & 13.25 & 12.75 & 12.43 & 11.95 & 11.53 & & \\
\hline
\end{tabular}


Table 2. Effect of treatment and storage interval on \% acidity of olive apple blended leather

\begin{tabular}{|l|l|l|l|l|l|l|l|l|l|}
\hline \multirow{2}{*}{ Treatments } & \multicolumn{6}{l|}{ Storage Intervals (Days) } & \multicolumn{2}{l|}{ \% Increase } & \multirow{2}{*}{ Mean } \\
\cline { 2 - 8 } & Initial & 30 & 60 & 90 & 120 & 150 & & \\
\hline \% Acidity rate \\
\hline OA0 & 0.33 & 0.35 & 0.38 & 0.41 & 0.45 & 0.49 & 32.65 & 0.4 \\
\hline OA1 & 0.42 & 0.44 & 0.47 & 0.5 & 0.52 & 0.55 & 23.64 & 0.48 \\
\hline OA2 & 0.46 & 0.49 & 0.51 & 0.54 & 0.57 & 0.6 & 23.33 & 0.53 \\
\hline OA3 & 0.49 & 0.53 & 0.56 & 0.59 & 0.61 & 0.63 & 22.22 & 0.57 \\
\hline Mean & 0.43 & 0.45 & 0.48 & 0.51 & 0.54 & 0.57 & & \\
\hline
\end{tabular}

Table 3. Effect of treatment and storage interval on color score of olive apple blended leather

\begin{tabular}{|l|l|l|l|l|l|l|l|l|l|}
\hline \multirow{2}{*}{ Treatments } & \multicolumn{6}{l|}{ Storage Intervals (Days) } & \multicolumn{2}{l|}{ \% decrease } & \multirow{2}{*}{ Mean } \\
\cline { 2 - 7 } & Initial & 30 & 60 & 90 & 120 & 150 & & \\
\hline Color score & 5 & 4.6 & 4.3 & 4 & 3.7 & 3.5 & 30 & 4.18 \\
\hline OA0 & 5 & 5.3 & 4.9 & 4.7 & 4.4 & 4.1 & 28.07 & 4.85 \\
\hline OA1 & 5.7 & 5.8 & 5.5 & 5.2 & 4.9 & 4.6 & 26.98 & 5.38 \\
\hline OA2 & 6.3 & 6.7 & 6.4 & 6.1 & 5.9 & 5.7 & 17.39 & 6.28 \\
\hline OA3 & 6.9 & 5.6 & 5.28 & 5 & 4.73 & 4.48 & & \\
\hline Mean & 5.98 & 5.6 & & & & & \\
\hline
\end{tabular}

Table 4. Effect of treatment and storage interval on taste score of olive apple blended leather

\begin{tabular}{|c|c|c|c|c|c|c|c|c|}
\hline \multirow[t]{2}{*}{ Treatments } & \multicolumn{6}{|c|}{ Storage Intervals (Days) } & \multirow[t]{2}{*}{$\%$ decrease } & \multirow[t]{2}{*}{ Mean } \\
\hline & Initial & 30 & 60 & 90 & 120 & 150 & & \\
\hline \multicolumn{9}{|l|}{ Taste score } \\
\hline OA0 & 6.3 & 5.8 & 5.4 & 5 & 4.7 & 4.4 & 30.16 & 5.27 \\
\hline OA1 & 6.5 & 6.3 & 6 & 5.7 & 5.4 & 5.1 & 21.54 & 5.83 \\
\hline OA2 & 6.8 & 6.5 & 6.3 & 6.1 & 5.8 & 5.5 & 19.12 & 6.17 \\
\hline OA3 & 7.4 & 7.1 & 6.8 & 6.5 & 6.3 & 6.2 & 16.22 & 6.72 \\
\hline Mean & 6.75 & 6.43 & 6.13 & 5.83 & 5.55 & 5.3 & & \\
\hline
\end{tabular}

Table 5. Effect of treatment and storage interval on texture score of olive apple blended leather

\begin{tabular}{|c|c|c|c|c|c|c|c|c|}
\hline \multirow[t]{2}{*}{ Treatments } & \multirow[b]{2}{*}{ Initial } & \multicolumn{4}{|c|}{ Storage Intervals (Days) } & \multirow[b]{2}{*}{150} & \multirow[t]{2}{*}{$\%$ decrease } & \multirow[t]{2}{*}{ Mean } \\
\hline & & 30 & 60 & 90 & 120 & & & \\
\hline \multicolumn{9}{|c|}{ Texture score } \\
\hline $\mathrm{OA} 0$ & 5.5 & 4.8 & 4.5 & 4.2 & 4 & 3.7 & 32.73 & 4.45 \\
\hline OA1 & 6.5 & 6.1 & 5.8 & 5.4 & 5 & 4.8 & 26.15 & 5.6 \\
\hline OA2 & 6.7 & 6.4 & 5.9 & 5.5 & 5.2 & 5 & 25.37 & 5.78 \\
\hline OA3 & 8.1 & 7.9 & 7.6 & 7.3 & 7.1 & 6.8 & 16.05 & 7.47 \\
\hline Mean & 6.7 & 6.3 & 5.95 & 5.6 & 5.33 & 5.08 & & \\
\hline
\end{tabular}

Table 6. Effect of treatment and storage interval on overall acceptability score of olive apple blended leather

\begin{tabular}{|l|l|l|l|l|l|l|l|l|l|}
\hline \multirow{2}{*}{ Treatments } & \multicolumn{6}{|l|}{ Storage Intervals (Days) } & \multirow{2}{*}{ \% decrease } & \multirow{2}{*}{ Mean } \\
\cline { 2 - 8 } & Initial & 30 & 60 & 90 & 120 & 150 & \\
\hline Overall acceptability score & 5.3 & 4.6 & 4.3 & 4.1 & 3.8 & 3.5 & 33.96 & 4.27 \\
\hline OA0 & 5.7 & 5.5 & 5.3 & 5.1 & 4.8 & 4.5 & 21.05 & 5.15 \\
\hline OA1 & 6.9 & 6.5 & 6.3 & 6 & 5.7 & 5.5 & 20.29 & 6.15 \\
\hline OA2 & 7.2 & 6.9 & 6.6 & 6.4 & 6.2 & 5.9 & 18.06 & 6.53 \\
\hline OA3 & 6.28 & 5.88 & 5.63 & 5.4 & 5.13 & 4.85 & & \\
\hline Mean & & & & & & & \\
\hline
\end{tabular}


cally as compared to others.

\section{References}

[1]. AOAC (2012) Official Methods of Analysis of AOAC International, 19th edition, volume II. Association of Official Analytical Chemists. Gaithersburg, Maryland 20877-2417, USA.

[2]. Ashaye O. A, S. O. Babalola, A. O. Babalola, J. O. Aina, S. B. Fasoyiro (2005) Chemical and organoleptic characterization of pawpaw and guava leathers. World J. Agric. Sci 1 (1): 50-51.

[3]. Babalola S. O, O. A. Ashaye, A. O. Babalola, J. O. Aina. (2000) Effect of cold temperature storage on the quality attributes of pawpaw and guava leathers. Afri. J. Biotech 1 (2): 61-63.

[4]. Bauernfeind J. C, C. R. Adams, W. L. Marisuch (1981) Carotenoids as colorants and vitamin A precursors. Academic press, New York.

[5]. Effah-Manu L, I. Oduro, A. Addo (2013) Effect of Dextrinized Sweet potatoes on the Physicochemical and Sensory Quality of Infra-Red Dried Mango Leather. J. F. Pro. Tech 4: 230.

[6]. Ekanayake S,L. Bandara ( 2002) Development of banana fruit leather. Annals of the Sri Lanka. Deptt. Agric 4: 353-358.

[7]. Garrido F, (1997) Table Olives, London, Chapman \& Hall.

[8]. Hussain T (2001) Food composition table for Pakistan. Govt. of Pak., Ministry of P \& D Islamabad.
[9]. Iman S, S. Bano, Shaukatullah, H. Naz. (2011) Physiochemical analysis and quality evaluation of intermediate moisture in apple slices. Pak. J. Biochem. Mol. Biol 44 (1): 27-31.

[10]. Jain P. K, P. K. Nema (2007) Processing of pulp of various cultivars of guava (psidium guajava 1.) for leather production. Agric. Eng. Int 9: 1-2.

[11]. Karmas E, R. S. Harris (1998) Nutritional evaluation of food processing. Van Nostrand Reinhold Publishers, New York. USA.

[12]. Krokida M. K, E. Tsami, Z. B. Maroulis (1998) Kinetics on color changes during drying of some fruits and vegetables. DRT 16: 667- 685 .

[13]. Larmond E (1977) Laboratory methods of sensory evaluation of foods. Publication 1673. Canada. Deppt. Agri. Ottawa.

[14]. Okilya S, I. M. Mukisa, A. N. Kaaya (2010) Effect of solar drying on the quality and acceptability of jackfruit leather. Electr. J. Envir. Agric. Food chem 9: 101-111.

[15]. Rao V. S, S. K. Roy (1980) Studies on dehydration of mango pulp II Storage studies of mango sheets/leather. Ind. Food Pack. 34: 72-79.

[16]. Steel R.G.D, J.H.Torrie (1997) Principles and procedures of statistics. A Biometrical approach, (3rd Edn) McGraw Hill book Co. NY. USA. 